\title{
A Study of Destination Brand Personality for Đà Nẵng Tourism
}

\author{
PHẠM TH!̣ LAN HƯONG \\ University of Đà Nẵng - phamlanhuong2008@gmail.com \\ NGUYẼ̃N MINH HUY \\ University of Đà Nẵng - huynguyenkt2160@gmail.com
}

\begin{abstract}
ARTICLE INFO
ABSTRACT

Article history:

Received:

June 142013

Destination brand personality is a rather new approach taken by many academic and empirical researches. Destination brand personality became an important structure to understand a tourist's

Received in revised form May 052014

Accepted: choice process, and a way of differentiating destinations and enhancing their competitiveness. The research focuses on analyses of destination brand personalities of Đà Nẵng based on domestic June 302014 tourists' perception in order to identify dimensions and strengths of personalities associated with Đà Nẵng as a destination. The results

Keywords:

brand personality, place

brand, destination brand, destination brand personality, dimensions of destination brand show that destination brand personality can be identified through three dimensions: sincerity, excitement, and competence-charming, which consist of thirteen items. Among them, sincerity and excitement are two principal factors of destination personality, compliant with findings by most previous researches. The new factor for destination of Đà Nẵng is competence-charming.
\end{abstract}

personality, Đà Nẵng. 


\section{INTRODUCTION}

Đà Nẵng has been known as an ideal site for tourism development in recent years. Building a strong destination brand is an important goal, therefore, one of effective means to achieve the goal is to identify and build destination brand personality as an important factor of destination image.

A destination known as a person with its own human characteristics can have a different and unique impression in tourists' minds compared to other competitors. It also raises interest, fondness, and strong attachment to the destination among tourists. Exploring the destination brand personality is a new approach for the world generally and Vietnam particularly. Today, arguments about brand personality in general and destination brand personality in particular are still highly controversial. Studying destination brand personality in Đà Nẵng context is a new approach in terms of both theory and practice. This research has three goals: (1) developing and testing a measure of Đà Nẵng destination brand personality based on perceptions of domestic tourists; (2) measuring strength of personality dimensions; and (3) suggesting some solutions for positioning and communication for Đà Nẵng's destination brand.

\section{THEORETICAL BASES AND METHODOLOGY}

\section{a. Theoretical Bases and Analytical Framework:}

\section{- Brand personality}

According to Aaker (1995), although brand is not a human being but it may have human characteristics resulting from brand communication and positioning. Brand personality reflects consumers' emotions about brands (Keller, 1993). Human characteristics are considered as a foundation for researches on brand personality. The study by Sirgy (1982) shows that a brand can be seen as a person and having human characteristics due to selecting self-image in consumer behavior. According to Aaker (1997), brand personality is defined as "the set of human characteristics associated with a brand".

\section{- Destination Brand}

Kotler (2002) posits that place marketing is an overall and long-term plan including special identities and advantages in order to attract investors, tourists, residents for their business opportunities and satisfy their demands, thereby promoting overall 
development of the place. Destination is a narrower concept of "place" considered as a tourist attraction, and a part of the concept of "place" in "place marketing".

Thus, destination brand personality is a narrow category of place brand which is defined as a country, city, region, town of destination that shapes "a network of associations in the consumers' mind based on the visual, verbal, and behavioral expression of a place, which is embodied through the aims, communication, values, and the general culture of the place's stakeholders and the overall place design" (Keller, 1993). Based on Aaker's branding approach (1991), Ritchie \& Ritchie (1998) define destination brand as a name, symbol, sign, logo or a combination of them intended to identify and distinguish it, thereby conveying promises and expectations to tourists' mind. Like a product or service, a destination can be totally associated with a brand, but building and developing a destination brand is more complicating than product/service brand building.

\section{- Destination brand personality}

The definition of destination brand personality is totally new in marketing. Compared to destination image studied in 1960s, according to Hosany \& Ekinci (2006), destination brand personality has been only explored in the recent years. The definition of destination brand personality is founded on and extended from the one of brand personality of product/service.

According to Hosany et al. (2006), destination brand personality is defined as "a set of human characteristics associated with a destination and identified by tourists' minds." As an inanimate identity, destination is associated with human traits and personalities and considered as independent factor to related citizens or tourists.

Aaker (1997) suggests that personality traits can be associated directly with a destination through several factors of the destination such as: infrastructure, hotels, hotel and restaurant staff, local residents or staple products of the destination, or destination image created by characteristics associated with target tourists. According to Cai (2002), destination personality could be indirectly build through the place marketing programs such as communication strategy, pricing strategy, infrastructure development or operation mode.

- Measuring destination brand personality 
There are many models for measuring the brand personality and the scale developed by Aaker (1997) is the most generalized and popular. It has been used for measuring personalities of products and services in different cultures.

Based on the model of the "Big Five" human traits (neuroticism, conscientiousness, agreeableness, extraversion and openness), Aaker (1997) uses lexical approach renovated by Goldberg (1990) to develop a brand personality scale by studying 37 brands of three types of product categories: symbolic, utilitarian, and both symbolic and utilitarian. As a result, a scale is developed with 42 traits divided into 15 clusters and five dimensions including: sincerity, excitement, competence, sophistication and ruggedness.

Meanwhile, Hosany \& Ekinci (2006) test applications of Aaker's brand personality scale to a destination and recognize the scale as a reliable, valid, and generalizable tool. Further studies of many researchers, such as Kilic et al. (2012), Sheng Ye (2012), and Murphy et al. (2007, 2008), also support and adopt this tool to measure destination brand personality.

\section{- Research framework}

This research selects Aaker's scale (1997) as the principal instrument for measuring destination brand personality. Theoretically and practically, advantages of this scale are as follows:

(1) It is widely used in many researches on destination brand personality.

(2) The study of Hosany et al. (2006) aims to test applications of Aaker's brand personality scale (1997) and states that it is really a reliable, valid, and generalizable tool to measure destination brand personality.

(3) Aaker's scale (1997) is also applied in researches on destination brand personality by Kilic \& Adem (2012) and Sheng Ye (2012). The results of those empirical researches also support previous view of Hosany et al. (2006) on compatibility and suitability of the scale.

(4) At present, researches on building and developing scales of brand personality associated with a destination do not ensure the reliability and generalization and still be a controversial topic, according to Kaplan et al. (2008). 
However, Aaker's brand personality scale (1997) is used for product, thus this scale should be applied in a flexible way to each destination and context of research (Hosay et al, 2006).

\section{b. Methodology:}

The research is conducted in three basic stages: the first preliminary study exploring personalities associated strongly with Đà Nẵng as a destination, the second preliminary study - selecting personalities of Aaker's scale (1997) that are associated with Đà Nẵng, and the official study - identifying and testing the scale for brand personality of destination Đà Nẵng.

Aaker's brand personality scale (1997), before conducting the survey is translated into Vietnamese and back-translation is performed to ensure an accuracy of the Vietnamese version and research background.

Statistical analysis softwares used for data processing and analysis include: Excel (Etables Utilities), SPSS 16.0 and AMOS 18.0. In addition, the paper also applies such analysis techniques as content analysis, exploratory factor analysis (EFA), the Cronbach's alpha reliability estimate, confirmatory factor analysis (CFA), and statistical analysis.

This research applies the non-probability sampling method that includes domestic tourists to Đà Nẵng with different frequencies in order to identify the strongest and the most sensible traits among the set of human characteristics. To help respondents give the most precise answers and avoid wrong associations, interviewers decide to interview directly with free association technique in which main images of Đà Nẵng are personified. Interviewers are required to give visual description without affecting respondents' thoughts by creating an assumed situation that is agreed upon by respondents. Additionally, to limit semantic errors or differences in dialects, the preliminary studies are conducted separately in terms of research time and space.

\section{- The first preliminary study}

This research was conducted in the period from March 2 to 10, 2013 through a survey of 100 respondents who were domestic tourists at many tourist attractions in Đà Nẵng such as Bà Nà Hill, Ngũ Hành Mountains, Sơn Trà Peninsula, the Hàn River, Linh Úng Pagoda, and Mỹ Khê and Phạm Văn Đồng beaches, etc. The survey, through free association, was conducted with open-ended questions in direct interviews. Specifically, respondents were required to list at least 5 words or phrases expressing 
personalities associated with Đà Nẵng as a person, and the words occurring with $\mathrm{a}$ frequency of $10 \%$ and more were selected (in accordance with experience from previous researches).

- The second preliminary study

At the same destinations as those of the first preliminary study, the second was conducted by interviewing 100 domestic tourists arriving in Đà Nẵng from March 12 to 25,2013 . The question was: "What characteristics do you associate with Đà Nẵng if you consider it a human being? Please show us the level you associate the following characteristics with Đà Nẵng." Respondents were asked to estimate the level of associating 42 personalities of Aaker's scale (1997) with Đà Nẵng (1 - not very associated, 5 - very associated). The traits that had scores less than or equal to 3 were removed and the official study included these results.

\section{- The official study}

The results of the first preliminary study (personalities founded associated with destination Đà Nẵng) and the second one (personalities of Aaker's scale suitable for destination Đà Nẵng) were integrated into the official questionnaire. The official study was conducted from April 2 to 25, 2013, in which more than 250 domestic tourists at similar destinations to those of two preliminary studies were interviewed with the same questions as the ones in the second preliminary study.

\section{RESULTS AND DISCUSSION}

\section{a. Results:}

- The first preliminary study

From 95 returned valid questionnaires, the first preliminary study collected 471 words and phrases, 74 of which, after being analyzed with Excel/eTables Utilities software, were selected to calculate the frequency. The gap between word frequencies was very small. Table 1 shows retained words and phrases that have a frequency of greater than 10\% (according to Echtner \& Ritchie [1993], the rate of $10 \%$ was used for attribute-based images while Echtner [1991] suggested that the rate of $20 \%$ was for researches on holistic images). 
Table 1: Selected Traits

\begin{tabular}{ccc}
\hline No. & Concept & Frequency (\%) \\
\hline 1 & Outdoorsy & 13.7 \\
2 & Energetic & 12.6 \\
3 & Friendly & 12.4 \\
4 & Routine & 11.3 \\
5 & Cheerful & 11.1 \\
\hline
\end{tabular}

Source: Result of the first preliminary study

There are three among retained words that match Aaker's scale (1997), including outdoorsy, cheerful and friendly. The remaining words, routine and energetic, are two new traits that are detected through tourists' perception.

- The second preliminary study

Of 100 questionnaires distributed, 98 returned ones are valid. The results of analysis of averages allow authors to retain 24 traits referring characteristics in Aaker's personality scale that have average values greater than 3 (Table 2). Sincerity and Excitement are two dimensions that have the most retained traits with 8 out of 12 traits and 6 out of 11 traits respectively, whereas Ruggedness is the dimension that has the most removed traits with 4 out of 5 traits.

Table 2: Retained and Removed Traits

\begin{tabular}{lll}
\hline $\begin{array}{c}\text { Personality } \\
\text { Dimensions }\end{array}$ & \multicolumn{1}{c}{ Retained Traits } & \multicolumn{1}{c}{ Removed Traits } \\
\hline Sincerity & $\begin{array}{l}\text { Down-to-earth, sincere, wholesome, } \\
\text { honest, cheerful, sentimental, } \\
\text { friendly. }\end{array}$ & $\begin{array}{l}\text { Family-oriented, small-town, real, } \\
\text { original. }\end{array}$ \\
& $\begin{array}{l}\text { Trendy, exciting, cool, young, up-to- } \\
\text { date, independent. }\end{array}$ & $\begin{array}{l}\text { Daring, spirited, imaginative, } \\
\text { unique, contemporary. }\end{array}$ \\
Excitement & $\begin{array}{l}\text { Hardworking, intelligent, successful, } \\
\text { leader, confident. }\end{array}$ & $\begin{array}{l}\text { Reliable, secure, technical, } \\
\text { corporate. }\end{array}$ \\
Sophistication & $\begin{array}{l}\text { Upper class, glamorous, good } \\
\text { looking, charming, smooth. }\end{array}$ & Feminine
\end{tabular}


Source: Result of the second preliminary study

By combining with results from the first preliminary study, a Đà Nẵng destination brand personality scale including six groups of personality dimensions with 26 traits is developed (Figure 1) in which 24 ones divided into five dimensions are from the Aaker's scale (1997) and two remaining traits constitute a new dimension.

Table 3: Pre-testing Đà Nẵng's Destination Brand Personality Scale PRETESTING ĐÀ NÃNG'S DESTINATION BRAND PERSONALITY SCALE

Personality dimensions

Sincerity

Excitement

Competence

Sophistication

Ruggedness

$X$

\section{Traits}

Down-to-earth, sincere, wholesome, honest, cheerful, sentimental, friendly.

Exciting, trendy, cool, young, up-to-date, \& independent.

Hardworking, intelligent, successful, leader, confident.

Upper class, glamorous, good looking, charming, smooth.

Outdoorsy

Energetic, routine

Source: Combination of results of two preliminary studies

- The official study

The survey interviews 250 tourists: $51.4 \%$ of them are male and $48.6 \%$ female. Regarding their age: $51.4 \%$ are in the $21-35$ age bracket constituting the biggest group while the smallest one are of 60 years or older occupying 5.2\%. Proportions of other age groups vary between $12 \%$ and $16 \%$.

After performing EFA (Principal Components, Varimax rotaion), eight out of 26 initial traits are removed because their community indexes and factor loadings are smaller than 0.5 . The second performance of EFA indicates that 18 remaining traits of five dimensions have variance extracted of $58.533 \%(>50 \%)$ and factor loadings equal to or greater than 0.5 which secures the robustness (Table 3 ). 
Table 3: Rotated Component Matrix (EFA)

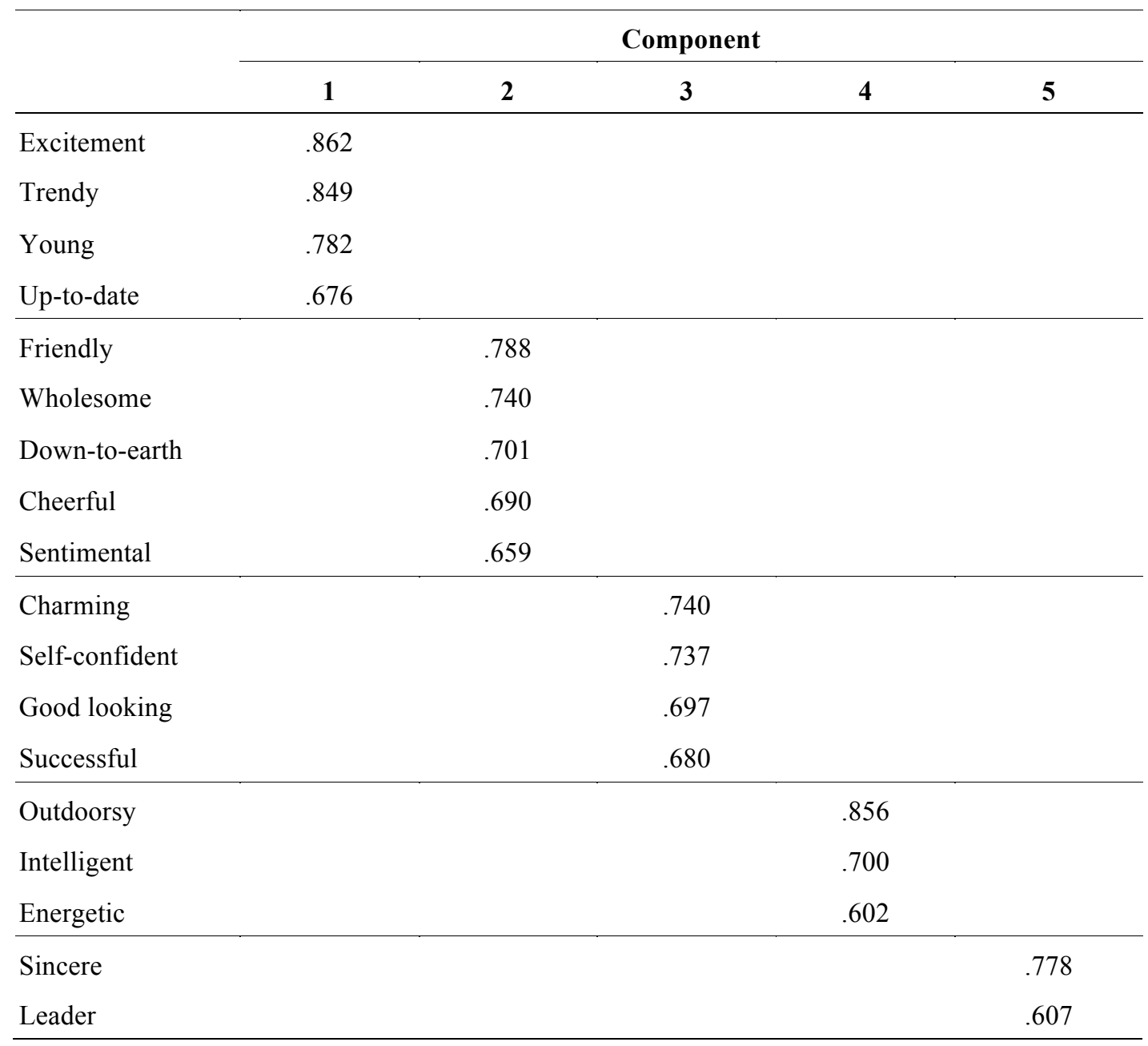

Source: Result of the official research

In the process, Croncbach's alpha is used for testing reliability with groups of personality dimensions with the result that the fifth dimensions in Table 3 (Cronbach's alpha is $0.115<0.6$ ) and the trait "Energetic" of the fourth dimension are removed (this decision makes the Cronbach's alpha rise from 0.587 to 0.637). Thus, four remaining dimensions are Excitement, Sincerity, Competence-charming, and Extraversion (Table 4). 
Table 4: Reliability Test with Cronbach's alpha

\begin{tabular}{l|c}
\multicolumn{1}{c|}{ Factors } & Cronbach's alpha \\
\hline F1: Excitement & 0.816 \\
Exciting & \\
Trendy & \\
Young & \\
Up-to-date & 0.767 \\
F2: Sincerity & \\
Friendly & \\
Honest & \\
Down-to-earth & \\
Cheerful & \\
Sentimental & \\
F3: Competence-Charming & \\
Charming & \\
Self-confident & \\
Good looking & \\
Successful & \\
F4: Extraversion & \\
\hline
\end{tabular}

Source: Result of the official research

Finally, CFA results (AMOS 16.0) remove two traits "Outdoorsy" and "Intelligent" from the fourth dimension because their standardized coefficients are smaller than 0.5 . As a result, there are only three dimensions left: Excitement, Sincerity and Competence-charming. As shown in Table 5, all model quality indexes meet the conditions of a good model. 
Table 5: Suitable indexes of CFA's model

\begin{tabular}{|c|c|}
\hline Statistical indexes & Standardized value \\
\hline \multicolumn{2}{|l|}{ Absolute Fit Measure (AFM) } \\
\hline P-value (Chi-square) & $0.000<0.05$ \\
\hline Goodness of Fit Index (GFI) & $0.925>0.9$ \\
\hline Adjusted Goodness of Fit Index (AGFI) & $0.890>0.9$ \\
\hline Root Mean Square Residual (RMR) & $0.025<0.05$ \\
\hline Standardized Root Mean Square Residual (SRMR) & $0.05<=0.05$ \\
\hline $\begin{array}{l}\text { Root Mean Square Error of Approximation } \\
\text { (RMSEA) }\end{array}$ & $0.05<0.067<0.08$ \\
\hline \multicolumn{2}{|l|}{ Incremental Fit Measure (IFM) } \\
\hline Comparative Fit Index (CFI) & $0.920>0.9$ \\
\hline Tucker Lewis Index (TLI) & $0.9>=0.9$ \\
\hline
\end{tabular}

Source: Result of the official research

After all analyses and tests (EFA, Cronbach's alpha, and CFA), the final scale includes three personality dimensions with 13 traits that can secure the reliability and validity (Figure 1). Dimensions are named according to terms used for the Aaker's scale (1997). Two personality dimensions Sincerity (including Friendly, Honest, Down-to-earth, Cheerful, and Sentimental) and Excitement (including Energetic, Trendy, Young, and Up-to-date) are similar to traits of Aaker's scale (1997); Competence-charming (including Charming, Self-confident, Good looking, and Successful) is created by the combination of traits in the facet Charming and dimension Competence of the Aaker's scale (1997). 


\section{Figure 1: Đà Nẵng's Destination Brand Personality Scale}

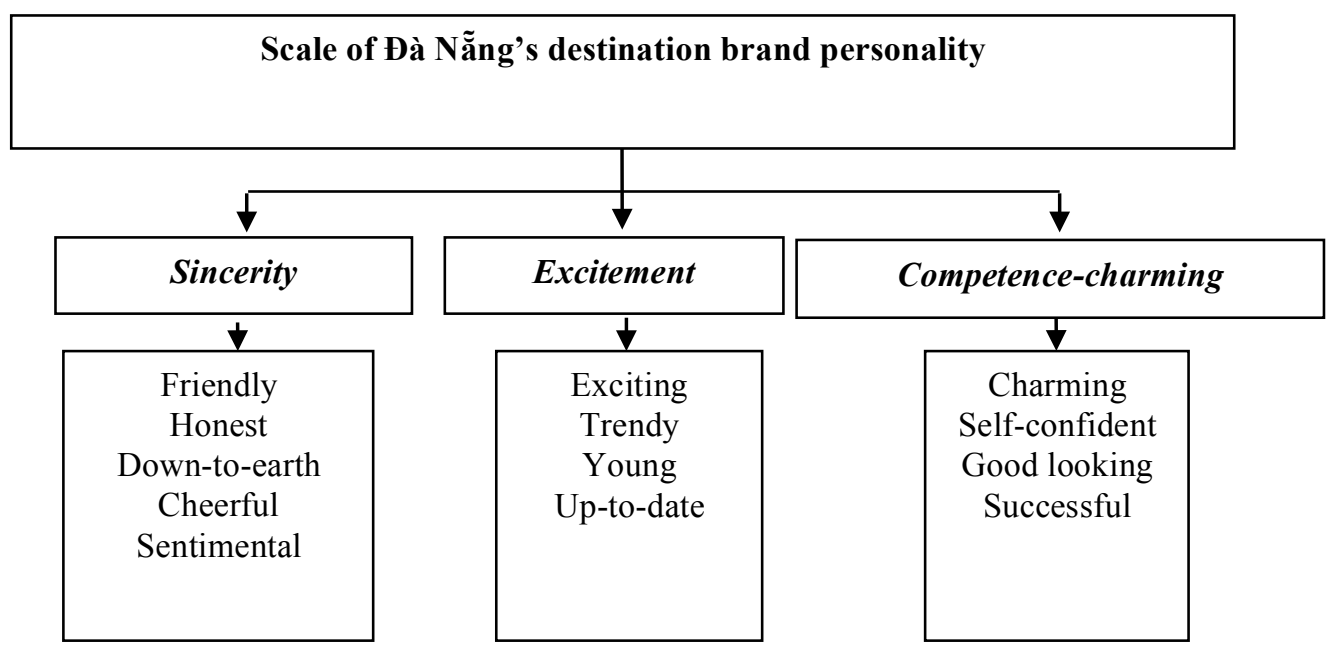

Table 5 shows the result of analysis of averages in which "Up-to-date", "Friendly" and "Charming" have the highest means in each dimension. These are the traits associated strongly with the destination in tourists' minds. Furthermore, Table 5 also indicates that "Excitement" and "Sincerity" are two major personality dimensions (their variance extracted values are highest and can explain $20.94 \%$ and $17.52 \%$ of total variance respectively).

Table 5: Summarized Results

\begin{tabular}{l|ccc}
\hline Factors (variance extracted \%) & Mean & Factor loadings & Cronbach's alpha \\
\hline F1: Excitement $(25,94 \%)$ & & 0.816 \\
Exciting & 3.7430 & 0.862 & \\
Trendy & 3.6827 & 0.849 & \\
Young & 3.8233 & 0.782 & 0.767 \\
Up-to-date & 4.0201 & 0.676 & \\
F2: Sincerity $(17,52 \%)$ & & & \\
Friendly & 4.0522 & 0.788 & \\
Honest & 3.9357 & 0.740 & \\
\hline
\end{tabular}




\begin{tabular}{l|lll}
\hline Down-to-earth & 3.7992 & 0.701 & \\
Cheerful & 4.0120 & 0.690 & \\
Sentimental & 3.8183 & 0.659 & 0.691 \\
F3: Competence-charming (11, & & & \\
$69 \%)$ & & & \\
Charming & 3.7590 & 0.740 & \\
Self-confident & 3.5462 & 0.737 \\
Good looking & 3.6707 & 0.697 \\
Successful & 3.6064 & 0.680 \\
\hline
\end{tabular}

Source: Result of the official research

\section{b. Discussion:}

This study applies Aaker's brand personality scale (1997) as well as definitions of destination brand personality to the context of Đà Nẵng. It achieves its important purpose by identifying and developing a destination brand personality scale for Đà Nẵng with three dimensions (Sincerity, Excitement, and Competence-charming) and 13 traits.

Firstly, the results show that Aaker's scale (1997) can be totally applied to measurement of destination brand personality. This finding bears a resemblance to the results of previous researches (i.e. Hosany et al., 2006; Murphy et al, 2007, 2008; and Sheng Ye, 2012) on destination brand personality. Three out of five dimensions of Aaker's scale (1997) are retained in this study, which is compliant with findings by Hosany et al (2006) and Kilic \& Adem (2012); and Sheng Ye (2012) who retain four out of five dimensions for their destination brand personality scales. Keeping the number of dimensions smaller than five and smaller than the number adopted for product/service brand personality scales is also supported by Hosany \& Ekinci (2006) and Caprara et al. (2001).

As mentioned in Section 2, there are many discussions on the scale of brand personality in general and of destination brand personality in particular. In reality, the results of researches on brand personalities of different destinations are not similar to each other. Nevertheless, "Sincerity" and "Excitement" are two major dimensions in this study that show similarities to the results of previous researches. Similar to 
previous studies, "Ruggedness" is removed from the scale in this study because it associates closely to American culture and changes when applied to other cultures (Yong et al, 2011).

Additionally, there appears a transfer of traits from one dimension to another (Murphy et al, 2007; and Hosany \& Ekinci, 2006). In this study, specifically, the trait "Friendly" moves from "Excitement" to "Sincerity". This transfer can be explained by differences in methods of selecting standards for analysis and/or in semantic contexts due to various cultural features.

"Competence-charming" is a new trait in this study, which is compliant with studies by Sheng (2012), Hosany et al (2006), and Murphy et al (2007, 2998). The appearance of the new trait can be explained by differences in characteristics of Đà Nẵng, as proven by many researches on other destinations on the world.

Finally, "Energetic" and "Routine" explored in the preliminary studied are removed after conducting EFA and CFA, due to the stability of structure of Aaker's scale (1997) makes these two new traits unable to be compatible and well associated with other traits of the scale.

\section{CONCLUSION AND POLICY RECOMMENDATIONS}

\section{a. Conclusion:}

This study develops and validates a Đà Nẵng destination brand personality scale that can secure the reliability and validity. This scale is extended from Aaker's brand personality scale, which is considered as a new finding of this study in the research on destination brand personality of Đà Nẵng in particular and Vietnam tourism in general. Moreover, the results confirm and support such discussions concerning destination brand personality in general and application of the Aaker's scale (1997) to a destination in particular. Additionally, theories of destination brand personality is also collected and systematized adequately in this paper, which can serve as a basis for development of the research on destination brand personality in the Vietnamese context.

\section{b. Policy Recommendations and Solution Implications:}

The identification of a destination brand personality scale allows the authors to suggest some theoretical and practical solutions to tourism development for Đà Nẵng.

- For academic field: 
First, methodological and logical bases of this study can serve as a basis for further and broader researches on destination brand personality, especially place brand personality, thereby building a common, consistent, reliable, efficient and highly generalized scale.

Second, further studies can make use of these results to explore more intensively relationship between destination brand personality and aspects of tourists' behavior and choice process, such as loyalty, attitude, evocation, satisfaction, compliance with personal perception, and self-expression value, etc., thereby expanding the scope of application.

Lastly, future studies can also use the suggested dimensions of the scale suggested by this study to examine more closely destination image or personal self-perception of a destination.

- Policies on Đà Nã̃ng's destination brand positioning and communication:

The results on three brand personality dimensions (Excitement, Sincerity and Competence-charming), especially the first two ones, and three most noticeable traits (Up-to-date, Friendly, and Charming) can help destination marketing managers develop and build up the effective strategies of destination brand positioning and communication to shape and convey values of the destination to tourists.

The mentioned personality dimensions can be used as strongly different, favorable and unique factors in destination brand positioning of Đà Nã̃ng's tourism compared to competitive places, especially coastal destinations in Vietnam such as Nha Trang, Hải Phòng, and Vũng Tàu, etc. To achieve this target, the personality dimensions are first used to design a brand identity system including logo, slogan, and mascot of Đà Nẵng's tourism.

In addition, the mentioned dimensions could be used for developing such local tourism products Swith compatible core values; modern, friendly and professional tourist attractions, and exciting and friendly festivals, etc.

The strategies and communication programs should give strong impression and attract tourists by conveying different feelings and images of Đà Nã̃ng as an excited, friendly and charming person ready to welcome travelers and visitors.

Last but not least, a new culture should be developed among Đà Nẵng residents, public services, and companies to turn them into friendly, civilized, modern and 
professional representatives in order to welcome and serve tourists. This effort aims at not only attracting tourists but also building a long-term relationship between tourists and Đà Nẵng City

\section{References}

Aaker, D.A (1991), Managing Brand Equity, Free Press New York.

Aaker, J.L. (1995), "Measuring the Human Characteristics of a Brand", paper presented at the annual conference of the Association of Consumer Research, Boston, October.

Aaker, J.L. (1997), "Dimensions of Brand Personality", Journal of Marketing Research, 34(3): 347.

Cai, L.A. (2002), "Cooperative Branding for Rural Destinations", Annals of Tourism Research, 29(3): 720-742.

Caprara G., C. Barbaranelli \& G. Guido (2001), "Brand Personality: How to Make the Metaphor Fit?” Journal of Economic Psychology, 22: 377-395.

Echtner, C.M \& J.R. Ritchie (1993), "The Measurement of Destination Image: An Empirical Assessment". Journal of Travel Research, 31(4): 3-13.

Echtner, C.M. (1991), “The Measurement of Tourism Destination Image”, doctoral dissertation, University of Cagary, Canada.

Goldberg, L.R. (1990), “An Alternative Description of Personality: The Big-Five Factor Structure”, Journal of Personality and Social Psychology, 59(6): 1216-1229

Hee, J.L \& G.S. Yong (2011), "Understanding and Measuring City Brand Personality (CPS) in the Context of South Korean Market”, International Journal of Tourism Sciences, 11(3): 1-20.

Hosany, S. \& Y. Ekinci (2006), "Destination Personality: An Application of Brand Personality to Tourism Destinations", Journal of Travel Research, 45: 127-139.

Hosany, S., Y. Ekinci \& M. Uysal (2006), "Destination Image and Destination Personality: An Application of Branding Theories to Tourism Places", Journal of Business Research, 59: 638642.

Kaplan, M.D., O. Yurt, B. Guneri \& K. Kurtulus (2008), "Branding Places: Applying Brand Personality Concept to Cities", European Journal of Marketing, 44(9): 1286-1304.

Keller, K. L (1993), “Conceptualizing, Measuring, and Managing Customer-Based Brand Equity”, Journal of Marketing, 57(1): 1-22.

Kilic, B. \& S. Adem (2012), "Destination Personality, Self-Congruity and Loyalty", Journal of Hospitality Management and Tourism, 3(5): 95-105. 
Kotler, P. et al. (2004), Tiếp thị địa phuoong châu Á (translated from Marketing Asian Places: Attracting Investment, Industry, and Tourism to Cities, States, and Nations), Fulbright Economics Teaching Program, Hà Nội.

Lê Thị Minh Hằng (2011), "Xây dựng thang đo nhân cách thương hiệu trong điều kiện văn hóa Việt Nam”, research project at University of Đà Nẵng.

Murphy, L., P.Benckendorff \& G. Moscardo (2007), "Destination Brand Personality: Visitor Perceptions of a Regional Tourism Destination", Tourism Analysis, 12: 419-432.

Murphy, L., P. Benckendorff \& G. Moscardo (2008), "Linking Travel Motivation, Tourist SelfImage and Destination Brand Personality", Journal of Travel \& Tourism Marketing, 22(2).

Ritchie, J.R \& R.B. Ritchie (1998), “The Branding of Tourism Destination: Past Achievements and Future Challenges", in Keller, P. (ed.), Destination Marketing: Scopes and Limitations, proceedings of the 1998 Annual Congress of the International Association of Scientific Experts in Tourism, Morroco: International Association of Scientific Experts in Tourism, 89-116.

Sirgy, M.J. (1982), “Self-Concept in Consumer Behavior: A Critical Review”, Journal of Consumer Research, 9(3): 287-300.

Sheng, Y. (2012), The Impact of Destination Personality Dimensions on Destination Brand Awareness and Attractiveness: Australia as Case Study, MSc, Faculty of Tourism, Macau University of Science and Technology, China. 